\title{
PENGARUH CITRA MEREK DAN PENGETAHUAN PRODUK TERHADAP KEPUTUSAN PEMBELIAN ULANG AIR MINERAL CLEO DI ALFAMIDI KOTA PALU
}

\author{
DESI \\ H. SYAMSUL BAHRI \\ PONIRIN \\ Program Studi S1 Manajemen Fakultas Ekonomi Universitas Tadulako \\ Email : desitan071296@gmail.com
}

\begin{abstract}
This study aims to determine the effect of brand image and product knowledge on the decision to repurchase mineral water CLEO in Alfamidi Jl. Martadinata Palu City. The independent variables used in this research are Company Image (X1), User Image (X2), Product Image (X3), Product Knowledge (X4), while the dependent variable is the repurchase decision $(Y)$. This type of research is quantitative. The method of this research is descriptive causal. The sample used in this research is as much as 75 respondents with the form of sampling using purposive sampling technique. Data analysis method used in this research is multiple linear regression analysis method. The results of this study indicate that simultaneously the simultaneous influence of brand image and product knowledge consisting of corporate image, user image, and product image significantly influence against the decision of CLEO Mineral Water Buyback in Alfamidi. and partially corporate image, user image, product image, product knowledge significantly influence to decision of re-purchase of mineral water CLEO in Alfamidi Jl. Martadinata Palu City.
\end{abstract}

Keywords: Brand image, product knowledge, Purchase Decision

\begin{abstract}
Abstrak
Penelitian ini bertujuan untuk mengetahui pengaruh citra merek dan pengetahuan produk terhadap keputusan pembelian ulang air mineral CLEO di Alfamidi Jl. Martadinata Kota Palu. Variabel independen yang digunakan dalam penelitian ini adalah Citra Perusahaan $\left(\mathrm{X}_{1}\right)$, Citra Pemakai $\left(\mathrm{X}_{2}\right)$, Citra Produk $\left(\mathrm{X}_{3}\right)$, Pengetahuan Produk $\left(\mathrm{X}_{4}\right)$, Sedangkan variabel dependen adalah keputusan pembelian ulang $(\mathrm{Y})$. Jenis penelitian ini adalah kuantitatif. Metode penelitian ini adalah deskriptif kausal. Sampel yang digunakan pada penelitian ini yaitu sebanyak 75 responden dengan bentuk pengambilan sampel menggunakan teknik purposive sampling. Metode analisis data yang digunakan dalam penelitian ini adalah metode analisis regresi linear berganda. Hasil penelitian ini menunjukkan bahwa secara serempak pengaruh serempak citra merek dan pengetahuan produk yang terdiri dari citra perusahaan, citra pemakai, dan citra produk berpengaruh signifikan terhadap terhadap keputusan pembelian ulang Air Mineral CLEO di Alfamidi. dan secara parsial citra perusahaan, citra pemakai, citra produk, pengetahuan produk berpengaruh signifikan terhadap keputusan pembelian ulang air mineral CLEO di Alfamidi Jl. Martadinata Kota Palu.
\end{abstract}

\section{Kata kunci: Citra merek, pengetahuan produk, Keputusan Pembelian ulang}

\section{PENDAHULUAN}

Salah satu kebutuhan pokok sehari-hari yang sangat penting bagi kehidupan mahluk hidup di dunia ini adalah air. Air merupakan sumber kehidupan yang diperlukan oleh setiap mahluk hidup, beragam aktifitas manusia berhubungan dengan air misalnya saja mencuci, mandi, minum dan sebagainya. Bagi manusia air sangatlah penting karena di dalam tubuh manusia terdiri dari $70 \%$ air. Air digunakan untuk membantu proses metabolisme tubuh. Kebutuhan air tiap orang kurang lebih 2 liter atau setara dengan 8-12 gelas perhari sesuai dengan berat badandan aktivitasnya.Bertambahnya tingkat kehidupan masyarakat dan persaingan pasar yang semakin ketat secara tidak langsung akan mempengaruhi usaha suatu perusahaan dalam mempertahankan pangsa pasar sehingga menyebabkan kebutuhan terhadap barang juga meningkat dan mempengaruhi perilaku saat melakukan pembelian. Produk air minum dalam kemasan (AMDK) dalam eksistensinya meluncurkan air minum murni merek CLEO yang 
diupayakan bisa memposisikan produknya agar dapat diterima konsumen, dengan membuat konsumen cenderung lebih memilih produk dengan citra merek yang baik dan terjamin kebersihan dan kesehatannya yang sesuai dengan manfaat yang didapatkannya.

Tanobel adalah identitas perusahaan PT. Sariguna Primatirta, yang pertama kali beroperasi pada 17 September 2003 dengan memproduksi air minum dalam kemasan. Air minum murni CLEO ini adalah air dalam kemasannya sudah dimurnikan, sehingga menjadi air minum murni $\left(\mathrm{H}_{2} \mathrm{O}\right)$ saja. Terdapat tambahan kandungan oksigen sebagai antioksidan yang dapat melawan radikal bebas ditengah polusi Kota yang makin hari makin bertambah.Sebelum adanya industrialisasi dan kendaraan bermotor tentunya di sekitar kita sangat baik dan mengandung oksigen yang cukup. Zaman sekarang terdapat perbedaan komposisi oksigen di kota besar makin memburuk. Tubuh manusia sangatlah memerlukan mineral maka dari itu PT. Bintang Jaya di Kota Palu menjadi pemasok CLEO di Sulawesi Tengah yang bertempat di Jalan Petalolo No.5 dan memiliki Gudang di Puebongo.Sejak Tahun 2013 PT. Bintang Jaya resmi beroperasi di Kota Palu dengan menjual Air Minum dalam Kemasan (AMDK) dengan diluncurkan produk air minum murni CLEO sebagai salah satu produk andalan,tidak butuh waktu lama air minum dalam kemasan ini langsung mencuri perhatian masyarakat. Tipe kemasan air mineral bermacam-macam ada yang cup 250ml, Botol 330ml, 550ml, 6 liter dan galon 19 liter. PT. Bintang Jaya kemudian melebarkan sayap dengan membuka cabang air murni CLEO ke berbagai daerah di Provinsi Sulawesi Tengah seperti Luwuk,Toli-Toli, dan Poso.

Tabel 1 Data Penjualan Air Minum CLEOper Jenis Kemasan 2017

\begin{tabular}{|c|c|c|c|c|}
\hline Produk & Oktober & November & Desember & Jumlah \\
\hline Cup 250 ml & 700 & 500 & 400 & 1600 \\
\hline Botol 330 ml & 1000 & 900 & 850 & 2750 \\
\hline Botol 550 ml & 1000 & 1800 & 2000 & 4800 \\
\hline Botol 1500 ml & 400 & 300 & 200 & 900 \\
\hline Galon 6 liter & 250 & 300 & 250 & 800 \\
\hline Galon 19 liter & 500 & 550 & 450 & 1500 \\
\hline
\end{tabular}

Sumber: Alfamidi Jl. Martadinata 2

Berdasarkan tabel 1 dapat dilihat bahwa data penjualan AMDK tiga bulan berturut-turut mengalami ketidakstabilan. hal ini dapat dijelaskan bahwa dari tabel tersebut yaitu pada bulan oktober jumlah yang terjual sebanyak 1600 unit. Kemudian pada bulan November 8450 unit dan pada bulan Desember terjual sebanyak 2300 unit. disini dapat dilihat dari penjualan dari bulan Mei, Juni, dan Juli mengalami ketidakstabilan atau penurunan. berdasarkan hasil wawancara dengan seorang berinisal $\mathrm{V}$ menyatakan pengetahuannya akan produk dan citra merek terhadap AMDK masih sangatlah kurang sehingga keputusan minat pembelian ulang dengan merek yang sama belum tentu terjadi.Menurut Sumarwan (2011) pengetahuan produk adalah kumpulan dari beberapa macam informasi mengenai produk. Menurut Waluyo dan Pamungkas (2003), definisi product knowledge adalah cakupan seluruh informasi akurat yang disimpan dalam memori konsumen yang sama baiknya dengan persepsinya terhadap pengetahuan produk. Peneliti melakukan penelitian di Alfamidi Jl.Martadinata karena Alfamidi adalah jaringan toko swalayan yang memiliki banyak cabang di Indonesia khususnya kota palu yang sudah memiliki 23 cabang di kota palu. Gerai ini lebih besar dari minimarket pada umumnya. Selain menjual buah dan sayur alfamidi juga menjual makanan, minuman dan barang kebutuhan lainnya. Sesuai uraian di atas, maka penelitian ini mengambil judul "Pengaruh Citra Merek dan Pengetahuan Produk Terhadap Keputusan Pembelian Ulang Air Mineral CLEO di Alfamidi Jl.Martadinata Kota Palu” 


\section{KAJIAN LITERATURE DAN PENGEMBANGAN HIPOTESIS}

\section{Citra Merek}

Menurut Tjiptono (2011) citra merek atau deskripsi merekadalah deskripsi tentang asosiasi dan keyakinan konsumen terhadap merek tertentu, dimana brand associations (asosiasi merek) merupakan segala sesuatu yang terkait dengan memori terhadap suatu merek. Asosiasi merek berkaitan erat dengan citra merek, yang didefinikan sebagai serangkaian asosiasi merek dengan makna tertentu.

Citra merek adalah sekumpulan asosiasi merek berbentuk dan melekat di benak konsumen. konsumen yang terbiasa mengguanakan merek tertentu cenderung memilih konsistensi yang dilakukan oleh konsumen, seperti tercermin dalam asosiasi yang terjadi dalam memori konsumen Keller \& Kotler (2009).Citra perusahaan diawali dengan adanya persepsi publik mengenai suatu perusahaan yang terbentuk dalam benak para pelanggan.untuk membentuk citra perusahaan yang positif, perusahaan perlu melakukan kegiatan yang terkait dengan lingkungan perusahaan, baik internasional maupun ekternal.

Menurut Simamora (2014) citra perusahaan adalah persepsi masyarakat terhadap jati diri suatu perusahaanatau gambaran singkat yang dimiliki oleh perusahaan yang diciptakan melalui akumulasi pesan-pesan yang diterima melalui pengalaman yang dirasakan oleh seluruh indera.Menurut Simamora (2014) citra pemakai adalah sekumpulan asosiasi yang dipersepsikan konsumen terhadap pemakai yang menggunakan suatu barang atau jasa, meliputi pemakai itu sendiri,gaya hidup atau kepribadian dan status sosial. Konsumen yang terbiasa menggunakan merek tertentu cenderung memiliki konsistensi terhadap citra merek. Jadi apabila suatu konsep merek yang kuat dapat dikomunikasikan secarabaik kepada pasar sasaran yang tepat, maka produk akan menghasilkan citra merek yang dapat mencerinkan identitas merek yang jelas. Menurut Simamora (2014) citra produk adalah sekumpulan asosiasi yang dipersepsikan konsumen terhadap sesuatu produk. Persepsi terhadap produk merupakan persepsi konsumen terhadap keseluruhan dari kualitas yang dimiliki oleh sebuah produk yang berkaitan apa yang diharapkan oleh konsumen. Citra produk adalah kesan, pendapat, atau tanggapan yang dimiliki oleh konsumen terhadap sesuatu objek tertentu.

\section{Pengetahuan Produk}

Sumarwan (2011) pengetahuan produk adalah kumpulan berbagai informasi mengenai produk, merek, terminology produk, atribut produk atau fitur produk, harga produk dan kepercayaan mengenai produk. Konsumen memiliki tingkatan pengetahuan produk (levels of product knowledge) yang berbeda, yang dapat dipergunakan untuk menerjemahkan informasi baru dan membuat pilihan pembelian.

\section{Pengertian Pembelian Ulang}

Menurut Andre (2009) pembelian ulang merupakan keinginan konsumen untuk menggunakan kembali produk yang sama dimasa yang akan datang. Terdapat dua kemungkinan yang dapat menyebabkan seseorang melakukan pembelian kembali suatu produk. Pertama, konsumen merasa puas dengan pembelian yang mereka lakukan. Kedua, pelanggan merasa tidak puas, tetapi mereka tetap melakukan pembelian kembali. Hal ini disebabkan karena mereka menganggap biaya yang harus mereka keluarkan untuk mencari, mengevaluasi, dan mengadopsi produk dengan merek lain (switching cost) terlalu tinggi.

\section{Kerangka pemikiran}

Produk AMDK merek CLEO yang di pasarkan oleh PT. Bintang Jaya memiliki kelebihan tersendiri dibandingkan Air mineral lainnya.Hal ini telah menjadi kebijakan pemasaran perusahaan dengan harapan produk yang di pasarkan dapat menembus pasar, serta mampu meraih pangsa pasar yang luas. Citra produk dipandang sebagai elemen penting didalam upaya mempengaruhi keputusan pembelian konsumen. Semakin baik dan berkualitas suatu produk, maka semakin tinggi kepuasan yang akan 
diterima oleh konsumen.Berdasarkan hal tersebut di atas maka dapat digambarkan kerangka pemikiran dari analisis pengaruh pengetahuan produk dan Citra merek terhadap keputusan pembelian kembali Air Mineral CLEO di Alfamidi Kota Palu pada gambar berikut:

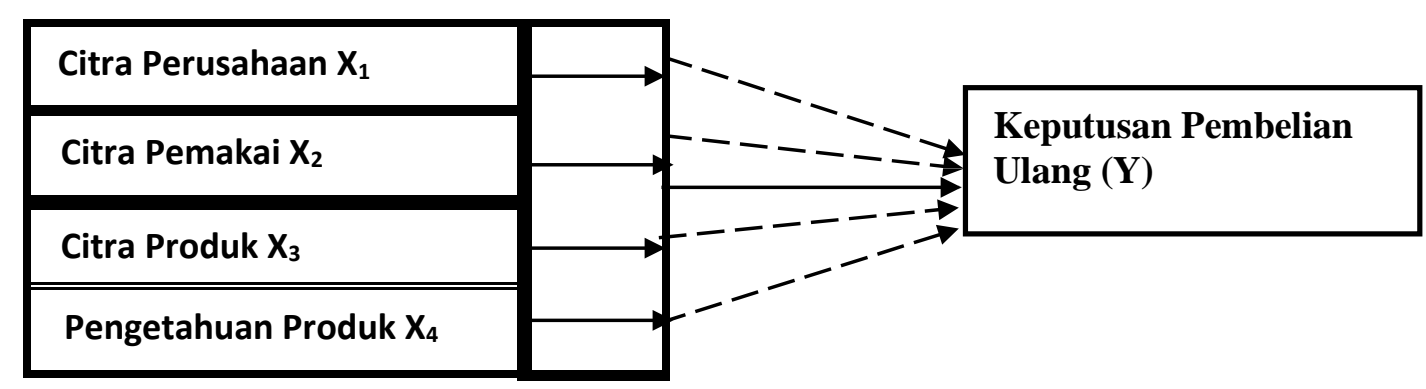

\section{Gambar 1 Kerangka Pemikiran}

\section{Hipotesis}

1. Citra perusahaan, citra pemakai, citra produk, dan pengetahuan produk secara serempak berpengaruh terhadap keputusan pembelian ulang Air Mineral CLEO di Alfamidi Kota Palu.

2. Citra perusahaan, secara parsial berpengaruh terhadap keputusan pembelian ulang Air Mineral CLEO di Alfamidi di Kota Palu.

3. Citra pemakai, secara parsial berpengaruh terhadap keputusan pembelian ulang Air Mineral CLEO di Alfamidi Kota Palu.

4. Citra produk, secara parsial berpengaruh terhadap keputusan pembelian ulang Air Mineral CLEO di Alfamidi Kota Palu.

5. Pengetahuan produk, secara parsial berpengaruh terhadap keputusan pembelian ulang Air Mineral CLEO di Alfamidi Kota Palu.

\section{METODE PENELITIAN}

Jenis penelitian yang digunakan adalah deskriptif-kausal untuk menganalisis hubungan sebab akibat antar variabel yaitu pengetahuan produk, citra merek terhadap keputusan pembelian ulang, Sebagaimana dikemukakan oleh Sugiyono (2014) bahwa penelitian deskriptif dilakukan dengan tujuan utama untuk memberikan gambaran atau deskriptif tentang suatu keadaan secara objektif.Selanjutnya menurut Sugiyono (2014) desain kausal adalah penelitian untuk menguji hubungan yang bersifat sebab akibat yang dihipotesiskan.

\section{Populasi dan Teknik Penarikan Sampel}

\section{a). Populasi}

Populasi adalah gabungan dari seluruh elemen yang bernentuk peristiwa, hal atau orang yang memiliki karakteristik serupa yang menjadi pusat perhatian penelti. Populasi dalam penelitian ini adalah konsumen CLEO yang telah melakukan pembelian ulang secara langsung dan mengkonsumsi produk CLEO minimal 2 kali dalam seminggu di Alfamidi Kota Palu.

b). Teknik Penarikan sampel

Teknik penarikan sampel adalah dengan menggunakan probability sampling, yaitu teknik pengambilan sampel yang tidak memberi peluang/kesempatan sama bagi setiap unsur atau anggota populasi untuk dipilih menjadi sampel.Hal ini dilakukan karena mengingat keterbatasan waktu yang ada. Metode pengambilan sampelnya menggunakan purposive sampling, yaitu teknik penarikan sampel dengan kriteria tertentu.Sugiyono (2014) memberikan saran-saran tentang ukuran sampel untuk penelitian yaitu: bila dalam penelitian akan melakukan analisis dengan multivariate (korelasi/regresi berganda misalnya), maka jumlah anggota sampel minimal 10 kali dari jumlah variabel yang diteliti. Misalnya variabel penelitiannya ada 5 (independen + dependen), maka jumlah 
anggota sampel $=10 \times 5=50$, Sugiyono (2014). Jumlah variabel dalam penelitian ini adalah 5 variabel yang terdiri dari variabel independen (citra perusahaan, citra pemakai, citra produk, pengetahuan produk) dan variabel dependen (kepuasan pembelian ulang). Jumlah sampel yang akan ditentukan oleh peneliti $15 \times 5=75$ responden.

\section{Defenisi Operasional Variabel}

Menurut Sugiyono (2013) menyatakan bahwa variabel penelitian adalah segala sesuatu yang berbentuk apa saja yang diterapkan oleh peneliti untuk dipelajari sehingga diperoleh informasi tentang hal tersebut, kemudian ditarik kesimpulan. Variabel yang digunakan dalam penelitian ini adalah empat variabel bebas dan satu variabel terikat. citra perusahaan $\left(\mathrm{X}_{1}\right)$, citra pemakai $\left(\mathrm{X}_{2}\right)$, citra produk $\left(\mathrm{X}_{3}\right)$, pengetahuan produk $\left(\mathrm{X}_{4}\right)$.Sedangkan variabel dependen $(\mathrm{Y})$ dalam penelitian ini adalah pembelian ulang.

\section{Metode Analisis}

Untuk menjawab permasalahan serta hipotesis yang diajukan digunakan alat analisis statistik, yaitu Regresi Berganda (Multiple Linear Regression). Adapun penggunaan regresi linear berganda terkait dengan permasalahan dan hipotesis yang diajukan dalam penelitian pengaruh variabel independen (X) terhadap variabel dependen (Y) melalui bantuan SPSS 16.0.

\section{HASIL DAN PEMBAHASAN}

\section{Hasil Penelitian}

Tabel 2 Hasil Uji Analisis Regresi Linear Berganda

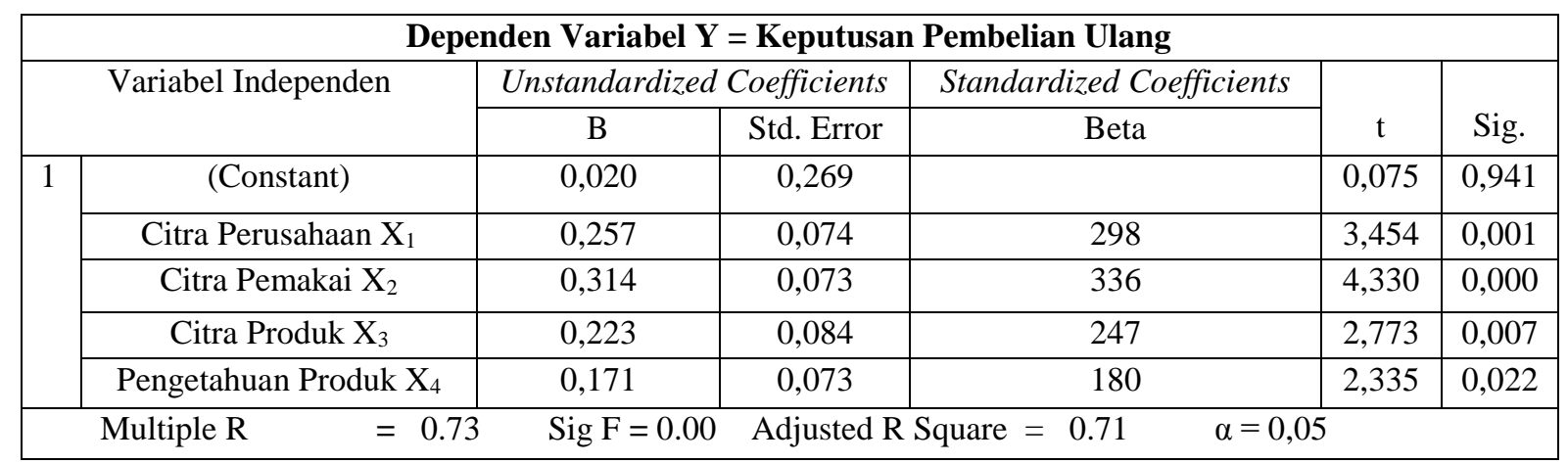

\section{Pembahasan}

Citra Perusahaan $\left(\mathrm{X}_{1}\right)$. Berdasarkan hasil penelitian ini, indikator-indikator yang digunakan untuk mengukur citra perusahaan $\left(\mathrm{X}_{1}\right)$ berpengaruh signifikan terhadap keputusan pembelian ulang di Alfamidi Kota Palu. Hal ini menunjukkan bahwa citra perusahaan dapat mempengaruhi keputusan pembelian ulang di Alfamidi Kota Palu.

Citra Pemakai $\left(\mathrm{X}_{2}\right)$. Berdasarkan hasil penelitian ini, indikator-indikator yang digunakan untuk mengukur Citra Pemakai $\left(\mathrm{X}_{2}\right)$ berpengaruh signifikan terhadap keputusan pembelian ulang di Alfamidi Kota Palu. Hal ini menunjukkan bahwa Citra pemakai dapat mempengaruhi keputusan pembelian ulang pada Alfamidi Jl.Martadinata Kota Palu.

Citra Produk $\left(\mathrm{X}_{3}\right)$. Berdasarkan hasil penelitian ini, indikator-indikator yang digunakan untuk mengukur Citra Produk $\left(\mathrm{X}_{3}\right)$ berpengaruh signifikan terhadap keputusan pembelian ulang di Alfamidi Kota Palu. Hal ini menunjukkan bahwa Interior Displ Citra produk dapat mempengaruhi keputusan pembelian ulang pada pada Alfamidi Jl.Martadinata Kota Palu.

Pengetahuan Produk $\left(\mathrm{X}_{4}\right)$. Berdasarkan hasil penelitian ini, indikator-indikator yang digunakan untuk mengukur pengetahuan produk $\left(\mathrm{X}_{4}\right)$ berpengaruh signifikan terhadap keputusan pembelian ulang di Alfamidi Kota Palu. Hal ini menunjukan bahwa pengetahuan produk Alfamidi Jl.Martadinata merupakan faktor penting yang menunjang keputusan pembelian ulang. 


\section{KESIMPULAN DAN SARAN}

\section{Kesimpulan}

1. Citra merek yang terdiri dari citra perusahaan, citra pemakai, citra produk dan pengetahuan produk secara simultan berpengaruh signifikan terhadap keputusan pembelian ulang Air Mineral CLEO di Alfamidi Kota Palu

2. Citra perusahaan secara parsial berpengaruh signifikan terhadap keputusan pembelian ulang Air Mineral CLEO di Alfamidi Kota Palu

3. Citra pemakai secara parsial berpengaruh signifikan terhadap keputusan pembelian ulang Air Mineral CLEO di Alfamidi Kota Palu

4. Citra produk secara parsial berpengaruh signifikan terhadap keputusan pembelian ulang Air Mineral CLEO di Alfamidi Kota Palu

5. Pengetahuan produk secara parsial berpengaruh signifikan terhadap keputusan pembelian ulang Air Mineral CLEO di Alfamidi Kota Palu

\section{Saran}

1. Kepada pemilik PT. Bintang Jaya untuk lebih mengembangkan lagi citra merek dan pengetahuan produk karena dalam penelitian ini citra merek dan pengetahuan produk berpengaruh cukup besar terhadap keputusan pembelian ulang yaitu sebesar $71.8 \%$, Khususnya $\mathrm{X}_{2}$, karena variabel ini yang berpengaruh dominan terhadap keputusan konsumen, sebaiknya PT. Bintang Jaya lebih memperhatikan tentang ciri khas produk CLEO.

2. Kepada pemilik PT. Bintang Jaya diharapkan juga lebih memfokuskan unsur $X_{1}$ yaitu produk yang selalu berinovasi dengan produknya karena merupakan faktor kedua dominan yang mempengaruhi keputusan konsumen dalam melakukan pembelian ulang.

3. Kepada pemilik PT. Bintang Jaya yaitu unsur $\mathrm{X}_{3}$ dan $\mathrm{X}_{4}$ yaitu bagian produk CLEO merupakan air minum dalam kemasan dan produk yang memiliki kualitas dan kemasan yang baik karena juga mempengaruhi keputusan pembelian ulang.

4. Kepada peneliti selanjutnya disarankan untuk memasukkan variabel lain, selain yang digunakan dalam penelitian ini sehingga lebih dapat mengukur sebab-sebab yang mempengaruhi keputusan pembelian ulang di Alfamidi Jl.Martadinata di Kota Palu, selain itu juga diharapkan untuk menggunakan ukuran sampel yang lebih besar dari jumlah sampel yang digunakan pada penelitian ini sehingga keakuratan hasil penelitian akan lebih terjamin.

\section{REFERENSI}

Andre. (2009). Analisis Hubungan antra Kepuasan Pelanggan dan Loyalitas Pelanggan terhadap Keinginan membeli Ulang. Business \& Management Journal Bunda Mulia,5(1), (Universitas bunda Mulia).

Kotler, P., \& Keller, K. L. (2009). Manajemen Pemasaran (13 ed.). Jakarta: Erlangga.

Purwanto Waluyo dan Agus Pamungkas, (2003). Analisis Perilaku Brand Switching Konsumen dalam

Pembelian Produk Handphone di Semarang. Jurnal Bisnis dan Ekonomi.

Sumarwan. (2011). Perilaku konsumen. PT Ghalia Indonesia.

Simamora. (2014). Pengaruh citra perusahaan, citra pemakai dan citra produk terhadap keputusan pembelian, 2 .

Sugiyono. (2013). Metode Penelitian Manajemen: pendekatan kuantitatif, kombinasi, Penelitian tindakan dan Peneltian Evaluasi. Bandung: Alfabeta.

Sugiyono. (2014a). Metode Penelitian Manajemen: pendekatan kuantitatif, kombinasi, Penelitian tindakan dan Peneltian Evaluasi (3 ed.). Bandung: Alfabeta.

Sugiyono. (2014b). metode penelitian Bisnis. Bandung: Alfabeta.

Tjiptono, F. (2011). Customer Loyalty. Jakarta: Gramedia pusta utama. 